\title{
Liquidity Profitability Trade-off: Evidence from Medium Enterprises
}

DOI: 10.7595/management.fon.2019.0004

\begin{abstract}
:
Research Question: This paper examines the impact of liquidity on the profitability of the Serbian polluting medium sized enterprises. Motivation: We study the impact of traditional liquidity indicators and indicators based on the cash flow on profitability. In domestic literature, a contribution in the field of financial stability analysis based on cash-flow is rare, consequently we use cash flow indicators as a liquidity measure. The focus of this paper is on the medium sized enterprises in Serbia being the major sources of environmental pollution. Medium-sized enterprises are the main drivers of economic growth. For improving environmental performance and applying technologies and processes that meet environmental requirements, it is necessary that the liquidity and profitability positions should be improved. The progress in the area of environmental protection is a relevant part of the accession process of Serbia to the EU. Idea: The idea of this paper was to empirically examine the liquidity profitability trade-off of selected enterprises. The research was conducted using return on assets as the dependent variable, three liquidity ratios and three cash flow based indicators as independent variables. Data: The financial analysis is based on the sample of 48 polluting medium-sized enterprises for the period 2010-2015. The official financial statements were taken from the Serbian Business Registers Agency. The data are used on an annual basis. Tools: We tested the panel regression model of profitability with the total number of observations being 288 . We estimated the unbalanced panel because our dataset had missing values. We used the standard pooled OLS estimator. Before we estimated panel regression model, we did a stationarity and cointegration analysis of sample data. Findings: The results show a significant impact of quick liquidity ratio, cash flow operating margin and cash flow investing margin on profitability measured by return on assets. However, there are no significant effects of the current liquidity ratio, the operating cash flow liquidity ratio and the cash flow financing margin on profitability. The conclusions of our paper refer to the selected enterprises in the observed periods. Contribution: This paper contributes to the literature concerning liquidity and profitability analysis, since we use cash flow indicators as a liquidity measure.
\end{abstract}

Key words: liquidity, profitability, cash flow, financial analysis, polluting medium enterprises

JEL classification: M20, L25, G32

\section{Introduction}

Enterprise managers pay a lot of attention to measuring and management of corporate liquidity and profitability and tend to achieve and maintain the optimal relation between these two concepts. The most useful analytical tools for assessing profitability and liquidity are financial statement ratios. They express relationships between various items from the financial statements. Researchers and practitioners have found that such ratios serve as effective indicators of various dimensions of profitability and liquidity. Managers primarily use financial performance measures, if they prefer to achieve financial goals and be successful (Milosavljevic et al., 2016).

Profitable enterprises that generate positive net cash flow from operating activities might be viewed as employing legal cash printing presses and the press generates cash as long as the enterprises continue to operate (Mulford and Comiskey, 2010, 7). A successful company is one achieving a positive financial result that 
actively manages cash flows, since the achieved profit is a reliable measure of the company's performance, and cash flows are considered to be the "bloodstream" of a company (Kieso et al., 2010). For the same reason, Checkley (1999) sees cash as "fuel" without which company cannot run its operations.

The aim of this paper is to examine the influence of liquidity on the profitability on a set of selected Serbian companies. Our research focuses on the impact of traditional liquidity indicators and indicators based on cash flow on the profitability measured by assets return rate. The impact of an enterprise's ability to service its matured liabilities on assets return is analysed on a sample of polluting medium enterprises in Serbia using the panel regression analysis for the period from 2010 to 2015 . The key research question refers to the extent to which the selected liquidity indicators affect the profitability of the analysed enterprises. We designed our first research question in order to determine the impact of traditional liquidity ratios on profitability measured by ROA (Return on Assets). The second question considers the influence of cash flow based indicators on profitability measured by ROA. This paper deals with the following hypotheses: the traditional liquidity indicators are associated with assets return rate and the cash flow based indicators are associated with assets return rate.

A special contribution of this paper lies in the fact that the analysis is focused on medium sized enterprises in Serbia being the major sources of environmental pollution in this country. Unlike other studies that usually use traditional liquidity indicators, we decided to use cash-flow indicators as a measure of liquidity. Cash flows information, with the other information provided in financial statements of enterprises are useful to stakeholders and other decision makers. This paper contributes to the literature concerning liquidity and profitability analysis, since it covers the impact of liquidity on ROA. Although we manged to find a positive statistically significant impact on the profitability for the quick liquidity ratio, we were not able to find statistical significance for current liquidity ratio, which coincides with findings by Pervan and Visic (2012) regarding Croatian enterprises. Our estimation results show that Cash flow operating margin and Cash flow investing margin have a statistically significant impact on profitability.

Apart from the introductory (first section) and the conclusion (sixth section) sections, the paper consists of four parts. A literature review is presented in the second section. The third section explains the empirical data used. The fourth section explains the methodology. The fifth section contains empirical results and discussions.

\section{Literature Review}

Profitability analysis focuses on the business and becomes a valuable tool for management planning, strategy analysis, decision making, as well as valuation, since higher profitability generates value (Penman, 2007). The assessment of profitability is usually done through the ROA and ROE (Return on Equity). Vieira (2010) highlights that ROA is not the best indicator to compare the enterprises' performance in different industries and, on the other hand, ROE will not provide a good comparison because small and negative equity levels can generate distorted indicators of profitability. Since most of the analysed polluting enterprises operate in the same industry, we can use ROA in this research.

Financial analysts use traditional liquidity ratios as key indicators of liquidity position of enterprises, but liquidity ratios are a mixture of ratios calculated on the basis of accounting flows, indirect cash flows and balance sheets. Accounting flows do not provide adequate information about the liquidity of a firm (Duhovnik, 2008). Cash flow as a measure of short-term financial stability does not have a long tradition of usage in the research literature. Some of the pioneers that used cash flow indicators to measure exposure to financial risks based on cash flows are Figlewicz and Zeller (1991), Carslaw and Mills (1991), Giacomino and Mielke (1993). Cash-flow indicators of financial stability can be useful in anticipating financial difficulties of enterprises (Rujoub et al., 1995), which is an assumption of successful business. Charitou et al. (2000) studied the association of earnings and cash flows with security returns using data from Japanese firms. They provided empirical evidence that cash flows have information content beyond earnings in explaining security returns. Analysing the cash flow sensitivity of investment, and (2009) conclude that accessibility of external capital is positively correlated with cash flows. Cash flow to liabilities ratio belongs to a group of most important ratios in the sense of financial instability prediction. In domestic literature, contributions in the field of financial stability analysis based on cash-flow are rare. We discuss three ratios for assessing a short-term liquidity position of the enterprise: current liquidity ratio, quick liquidity ratio and operating cash flow liquidity ratio.

Saleem and Rehman (2011) reveal the relationship between liquidity and profitability indicators. The results of their study show that there is a significant impact of only liquid ratio on ROA. There is no significant effect of current ratio and quick ratio. Khidmat and Rehman (2014) conclude that liquidity has a high positive ef- 
fect over return on assets of listed chemical companies of Pakistan. Eljelly (2004) does an empirical study in an emerging market considering a trade-off between liquidity and profitability. Vieira (2010) analyses the relationship between liquidity and profitability of the main airline companies in the world and shows a significant positive correlation between liquidity and profitability in the short and medium terms.

Rehman et al. (2015) investigated the relationship between liquidity and profitability of companies listed in the Saudi Stock Exchange Tadawul from 2008 to 2012. The overall results revealed that there was only one positive significant relationship between ROA and Current Ratio, while other investigated relationships those between ROA and Quick and Cash Ratio, as well as between ROE and 3 mentioned liquidity variables - were not statistically significant. The same type of relationship was investigated by Alagathurai (2013) who finds a significant relationship between liquidity and profitability among listed trading companies in Sri Lanka. In the case of listed manufacturing companies in Sri Lanka, the study for the period 2008-2012 also revealed a significant relationship between liquidity and profitability (Priya and Nimalathasan, 2013). Priya and Nimalathasan (2013) used operating cash flow ratio as a liquidity measure - the results of the study showed that operating cash flow ratio was significantly correlated with return on equity. Huang and Mazouz (2018) investigated the impact of excess cash on the liquidity risk and liquidity premium using data for NYSE/AMEX/NASDAQ common stocks of US industrial firms. They showed that excess cash improved trading continuity and reduced both liquidity risk and the cost of equity capital. However, the direct effect of excess cash on firm value was negative, but the indirect effect through liquidity was significantly positive. A similar result could be found in (2010) who claims that high excess cash companies invest considerably more in the future than their low cash peers, but do not experience a higher future profitability.

Ben-Caleb et al. (2013) studied the relationship between liquidity management and profitability of manufacturing companies listed on the Nigeria stock exchange for the period 2006-2010. The results revealed that current ratio and liquid ratio were positively associated with profitability, while cash conversion period was negatively related with profitability. The association in all cases was, however, statistically insignificant, indicating a low degree of influence of liquidity on the profitability of manufacturing companies.

Zygmunt's (2013) empirical research for Polish listed IT companies proved the existence of a statistically significant relationship between liquidity and profitability. Zygmunt (2013) measured liquidity by current ratio, quick ratio, receivable conversion period, inventory conversion period, accounts payables conversion period and cash conversion period. Since liquidity, however, can also be described by cash flow indicators, Zygmunt (2013) considers the aforementioned indicators in his research of liquidity-profitability relationship. Bolek and Wili'nski (2012) analysed the influence of liquidity on profitability of Polish construction sector companies. Their study revealed that the financial liquidity influenced profitability for the period 2000-2010, but only quick liquidity ratio had a statistically significant influence on ROA.

Zainudin (2006) examined the trade-off between liquidity and profitability on a sample of small and mediumsized enterprises in the Malaysian manufacturing sector for the period 1999-2003. Their analysis revealed that there was a statistically significant moderate positive association between liquidity (measured by current ratio and working capital to total assets ratio) and profitability. Liquidity-profitability trade-off is also investigated for non-financial companies in the sugar industry of Pakistan (Safdar et al. 2016). The results of this study, one that covers the period between 2007 and 2011, articulated that liquidity (measured by traditional indicators) of sampled companies is positively linked to their profitability. Liquidity can be observed in line with market returns. Rad et al. (2016) analysed the relationship between the liquidity factor and all strategies' returns, also between the liquidity factor and market excess returns.

Pervan and Visic (2012) evaluated the influence of the enterprise's size on the business success of Croatian companies and showed that current ratio did not prove to be an important explanatory variable of an enterprise's profitability. Zenzerovic (2009), analysing the Croatian experience in the business's financial problems prediction uses the multiple discriminant analysis that includes, inter alia, solvency and liquidity ratios. He emphasizes the importance of liquidity, solvency, profitability ratios and cash flow-based ratios as representative ratios. Pervan et al. (2012) focus on the relationship between ownership structure and performance of Croatian listed firms, and they show that firm liquidity positively affects the firm's profitability.

Research about the relation between profitability and liquidity in Serbia is rare, methodologies are limited, they often use simple correlation analysis. More advanced research can be found in Dencic-Mihajlov (2015). She used current liquidity ratio and ROA to investigate how large and medium-sized companies listed on the Belgrade Stock Exchange manage their profitability during periods of recession. The results show that bigger and more liquid companies demonstrate higher profitability. In order to evaluate this relationship on the wholesale and retail trade market in Serbia, Lukic (2012) shows that the wholesale and retail trade liq- 
uidity in Serbia is unsatisfactory for the period 2006 - 2010 and that an appropriate balance between profitability and liquidity is needed for improving business and financial performance in that sector. Jovanovic et al. (2017) developed a model for predicting illiquidity, with a focus on large companies in Serbia. Analysing financial indicators as predictors of illiquidity of large companies in Serbia, they have shown that return on total assets and return on equity, inter alia, are significant in the prediction of illiquidity. Andjelic et al. (2016) promote modern methods of financial management. These methods allow them to identify and monitor the needs for financial resources and their sources.

There is some literature connecting liquidity, profitability and pollution. This is especially relevant for China and other rapidly developed economies that are paying high environmental and pollution costs. Wu et al. (2018) investigated the relations among the air pollution, stock returns, and trading activity using daily stock returns, turnover, illiquidity and volatility for each firm as dependent variables. They have found that air pollution affects stock prices in Chinese stock markets mainly through home bias and has significant negative effects on local returns by decreasing volatility and trading. Hussain et al. (2018) explored the linkage between companies' sustainability performance, sustainability disclosure and financial performance using data from US companies belonging to the Global Fortune 100 best-performing companies list. They conclude that firms that invest more in sustainability achieve greater profitability. Vastola et al. (2017) contributed to the discussion on the relationship between environmental and financial performance. By using a sample of 954 companies, they provided evidence that specific cultural orientations significantly affected the extent to which the financial performance (i.e., ROA and ROE) as well as market value of firms were influenced by improvements in corporate environmental performance, in both the short-term and the medium-term.

\section{Empirical Data}

We tested the panel regression model of profitability on the sample that includes the medium-sized polluting enterprises. It is a group of 48 medium-sized enterprises operating in Serbia, whose plants are major sources of environmental pollution. According to key development indicators, medium-sized enterprises in Serbia are the main drivers of economic growth. We opt for medium-sized enterprises, since only those firms that do financially well can afford to spend more of their resources on cleaner technologies. For improving environmental performance and applying technologies and processes that meet environmental requirements, liquidity improvement, strengthening of the ability to generate cash flows from internal sources and profitability improvement are necessary.

The sample is selected from the PRTR register of major sources of pollution in Serbia (SEPA, 2017). Serbia belongs to countries that are part of the Europe-wide register (E-PRTR) which provides easily accessible key environmental data from industrial facilities. Harmonization with European standards in the area of environmental protection is part of the process of accession of Serbia to the European Union. The adoption and implementation of the standards covered by Chapter 27 make the negotiating process of Serbia complex and challenging. The aforementioned regulations within this area make one third of the total number of the EU regulations (GRS, 2018).

The annual financial statements on the basis of which the dependant and independent variables are determined were taken from the Serbian Business Registers Agency. The set of the analysed financial statements consists of the balance sheet, the income statement and the cash flow statement. Financial statements for the period 2010 through 2015 are analysed. The data are given on an annual basis. The number of analysed financial statements changed during the period under observation, as for certain periods financial statements were not publicly available and some enterprises were established during the stated period, which made collating and updating of data used in our research more difficult.

\section{Methodology}

The panel data series are provided for the given sample of 48 medium-sized polluting enterprises and over the period under observation, from 2010 through 2015, with the total number of observations being 288.

We used six indicators (three liquidity ratios and three cash flow based indicators) for our panel regression model of profitability. After analysing different types of measures of firm performance, we decided to use the ROA. It is an indicator often used in the literature and in practice as one of the key indicators of enterprise profitability. The ROA rate is obtained by dividing the net financial result of enterprise $i$ for period $t$ by the operating assets value of enterprise $i$ at the end of the fiscal year $t$. 
As the dependent variable is ROA, and regressors are CLR, QLR, CFOL, CFOM, CFIM, and CFFM, we follow the regression with the panel data:

$$
R O A_{i t}=\alpha+\beta_{1} C L R_{i t}+\beta_{2} Q L R_{i t}+\beta_{3} C F O L_{i t}+\beta_{4} C F O M_{i t}+\beta_{5} C F I M_{i t}+\beta_{6} C F F M_{i t}+\varepsilon_{i t}
$$

We include $\alpha$ and ${ }_{\text {it }}$ to capture the portion of return not explained by CLR, QLR,CFOL, CFOM, CFIM, and CFFM as in Clinch et al. (2002).

- $\mathrm{ROA}_{\text {it }}$ is Return on assets of enterprise $i$ in period $t$, where $\mathrm{i}=1, \ldots, 48, \mathrm{t}=2010, \ldots, 2015$.

- $\mathrm{CLR}_{\text {it }}$ is Current liquidity ratio of enterprise $i$ in period $t$.

- QLR $_{\text {it }}$ is Quick liquidity ratio of enterprise $i$ in period $t$.

- $\mathrm{CFOL}_{\text {it }}$ is Operating cash flow liquidity ratio of enterprise $i$ in period $t$.

- $\mathrm{CFOM}_{\mathrm{it}}$ is Cash flow operating margin of enterprise $i$ in period $t$.

- CFIM it $_{\text {is }}$ Cash flow investing margin of enterprise $i$ in period $t$.

- CFFM ${ }_{i t}$ is Cash flow financing margin of enterprise $i$ in period $t$.

- it is the error term, independently and identically distributed with zero mean.

- The a parameter represents the overall constant in the model.

We tested the panel regression model of profitability on the sample that includes the medium-sized polluting enterprises. Using Hausman's test we found that the fixed effects model was appropriate, as Baltagi (2005) mentioned - the fixed effects model is an appropriate specification if we are focusing on a specific set of $N$ firms.

We estimated the unbalanced panel because our dataset had missing values. The assessment panel given with equation (1) is based on the standard pooled OLS estimator. Kao's Residual Cointegration Test was applied to check the long-run model variable cointegration. We obtained that ADF t-Statistic -0.874 and $p=0.191$, meaning that variables were not cointegrated in the long-run, therefore there was no need to evaluate the panel dynamic OLS. As in Vătavu (2014), unit-root tests were applied on every variable included in the panel data in order to examine if data were stationary. According to test PP-Fisher Chi-square and Hadri Z-stat all variables in the panel dataset were stationary.

\section{Results and Discussions}

A summary of descriptive statistics of profitability, liquidity indicators and cash flow components is given in Table 1. Our measure of profitability, ROA, has a mean of 1.80 , a median of 1.09 , and a standard deviation of 12.51. A large standard deviation tells us about a large variability in profitability of the selected Serbian medium-sized enterprises. A similar result is obtained for Turkish manufacturing firms showed by Isik and Tasgin (2017). Each variable also exhibits substantial skewness (i.e., a large mean relative to the median).

Table 1: Descriptive statistics for the full sample (2010-2015)

\begin{tabular}{|l|r|r|r|}
\hline Variables & \multicolumn{1}{|l|}{ Mean } & \multicolumn{1}{l|}{ Median } & \multicolumn{1}{l|}{ St. dev. } \\
\hline ROA & 1.80 & 1.09 & 12.51 \\
\hline CLR & 2.14 & 1.30 & 2.37 \\
\hline QLR & 1.12 & 0.67 & 1.35 \\
\hline CFOL & 0.33 & 0.09 & 0.81 \\
\hline CFOM & 62.86 & 5.32 & 413.82 \\
\hline CFIM & 3.25 & 2.18 & 11.92 \\
\hline CFFM & -0.23 & -0.80 & 16.63 \\
\hline
\end{tabular}

Source: Authors' calculations.

CLR as a liquidity measure of the analysed enterprises has a mean of 2.14. According to a traditional banking financing rule, the current-assets-to-current-liability ratio is $2: 1$. The interpretation of this rule corresponds better to setting the lower limit than the norm. The literature avoids setting rigid and generally applicable norms, stating that a primary usefulness of an indicator is that it measures enterprise capacity to cover shortterm liabilities. The CLR median of 1.3 means that $50 \%$ enterprises have a good ability to service short-term liabilities with available current assets. The Charted Institute of Management Accountants - CIMA (2010), and 
Ghasemi and Ab Razak (2016) suggest ratios for evaluating liquidity risks. On the basis of these studies, we have found that the mean value of the current ratio is 2.14 , and it is over 1.5 (CIMA suggestion) which means that it is a low liquidity risk for this kind of Serbian enterprises.

The quick liquidity ratio is a much more reliable and a more conservative test of liquidity than the current liquidity ratio. The common QLR norm is 1:1, which corresponds to our result (QLR mean of 1.12). The QLR median of 0.67 shows that the value of liquid assets of more than $50 \%$ enterprises is not sufficient to cover short-term liabilities. The mean value of quick ratio is 1.12 , which means that Serbian medium-sized polluting enterprises are between low and average liquidity risk according to the CIMA suggestion (CIMA, 2010). Stevanovic and Marinkovic (2018) compare the average current and quick liquidity ratios of the selected polluting enterprises with the liquidity of medium enterprises sector and the whole Serbian economy, and conclude that Serbian medium polluting enterprises outperform medium enterprises sector and the whole Serbian economy.

The liquidity indicator based on operating cash flow has a mean of 0.33 . This result is relatively good given that in the literature authors use the norm of the level of 0.4 , for the short-term liabilities coverage with the net operating cash flow. The CFOL median and standard deviation of 0.09 and 0.81 , respectively, show a huge variability of this indicator.

With each cash flow component, the standard deviation is relatively high, meaning that cash-flow variability is pronounced over time. The median of these indicators shows extreme values. According to the theory and practice, enterprises prefer to finance their activities from internally generated cash flows. The high CFOM mean suggests that enterprises from our sample have a strong ability to generate cash flows from internal sources. The positive mean of CFIM shows that cash outflows used by investing activities are higher than cash inflows provided by investing activities. Approximately in only $17 \%$ of the analysed enterprises the value of cash receipts from investing activities is higher than that of outflows from investing activities. As we observed total investment cash inflows and outflows, the limitation in this part of the research is related to the fact that the cash flow statement does not provide information on the clean investments of enterprises. The negative mean of CFFM shows that cash outflows used by financing activities are higher than cash inflows provided by financing activities.

In Table 2, we present a summary of statistics from regressions of ROA on cash flow and liquidity components of Serbian enterprises, for the period 2010 to 2015.

Table 2: Summary of statistics from regressions of ROA on cash flow and liquidity components for the period $2010-2015$

\begin{tabular}{|l|l|c|}
\hline ROA-dependent variable & Coefficient & t-Statistic \\
\hline Intercept & 0.577 & 0.572 \\
CLR & -0.698 & -0.910 \\
QLR & $2.536^{\star *}$ & 2.087 \\
CFOL & -0.942 & -0.728 \\
CFOM & $-0.002^{\star * *}$ & -3.030 \\
CFIM & $0.087^{\star}$ & 1.677 \\
CFFM & -0.020 & -0.496 \\
& & \\
R-squared & 0.592 & \\
Adjusted R-squared & 0.498 & \\
F-Statistic & $6.268(p=0.000)$ & \\
\hline
\end{tabular}

Notes: ${ }^{*}{ }^{* *},{ }^{* *}$ Denote $\mathrm{p}$-value less than $0.10,0.05$, and 0.01 , respectively. Source: Authors' calculations.

The results in Table 2 show that CLR and CFOL do not have a significant impact on profitability, while the QLR has a positive statistically significant impact on the profitability (ROA) at the level of $5 \%$. Therefore, improving efficiency of liquid asset management leads to a higher value of QLR that has a positive effect on profitability. Consequently, the hypothesis that liquidity measured by traditional liquidity indicator affects profitability cannot be rejected.

The result that the current liquidity ratio is statistically insignificant and does not have an impact on the selected Serbian enterprises' profitability coincides with Pervan and Visic (2012) for Croatian firms. Also, this result is in line with the result by Saleem and Rehman (2011) for Pakistani companies in the oil and gas sec- 
tors. However, our result does not coincide with Dencic-Mihajlov (2015) for large and medium-size Serbian enterprises, and with Pervan et al. (2012). The result that quick liquidity ratio is statistically significant and affects the selected Serbian enterprises' profitability does not coincide with Saleem and Rehman (2011).

Table 2 indicates that the CFOM has a statistically significant impact on profitability at the level of $1 \%$, but with a small negative coefficient value of -0.002 . The CFIM has a positive statistically significant impact on ROA at the level of $10 \%$ (coefficient value of 0.087 ). Considering that the increase in investments is a generator of future rentability flow and cash flow, clean technologies investments as part of total investments can also be drivers of profitability. Consequently, the hypothesis that cash flow affects profitability cannot be rejected. The CFFM does not have a statistically significant relationship with profitability. Table 2 shows that R-squared value is 0.592 , indicating that $59.2 \%$ variance in the Return on Assets as a dependent variable can be explained through six independent variables which we used.

\section{Conslusion}

In this paper, we tested the impact of selected Serbian enterprises' liquidity on their profitability using the panel regression model for the period 2010-2015. For that purpose, we used traditional liquidity indicators (current liquidity ratio and quick liquidity ratio) and indicators based on cash flow (operating cash flow liquidity ratio, cash flow operating margin, cash flow investing margin, cash flow financing margin). The contribution of this paper is our focus on the polluting medium-sized enterprises in Serbia and the use of cash flow indicators as a liquidity measure. The CLR as a liquidity measure of analysed enterprises has a mean of 2.14 and QLR has a mean of 1.12. This result is in line with traditional banking financing rules. The CLR median of 1.3 means that $50 \%$ of enterprises have a good ability to service their short-term liabilities with available current assets. The QLR median at the level of 0.67 shows that the value of liquid assets for more than $50 \%$ of enterprises is not sufficient to cover their short-term liabilities. The liquidity indicator based on operating cash flow has a mean of 0.33 , and this is a relatively good result. High standard deviations of all cash flow components show a huge variability of cash flow during the observed period. The median of these indicators shows extreme values. The high CFOM mean suggests that selected polluter medium enterprises have a strong ability to generate cash flows from internal sources. The results of our study show that there is a significant impact of quick liquidity ratio, cash flow operating margin and cash flow investing margin on the profitability of the selected Serbian enterprises. The quick liquidity ratio (QLR) has a positive statistically significant impact on the profitability, but it does not coincide with Saleem and Rehman (2011). The cash flow operating margin has a small negative impact on profitability but the cash flow investing margin has a small positive impact on assets return. There is no significant impact of the current liquidity ratio, operating cash flow liquidity ratio and cash flow financing margin on ROA. The current liquidity ratio is statistically insignificant, and this result is in line with Pervan and Visic (2012), and Saleem and Rehman (2011). The conclusions of our paper are restricted to the selected enterprises and to the observed period. A recommendation to the management of polluting medium enterprises refers to the fact that improving the efficiency of liquid assets management and current liabilities, as well as increasing investments in clean technologies can be profitability drivers. A future research can be made by testing for coefficient equality across cash flow components, similarly to Clinch et al. (2002) who investigate whether components of cash flows convey information relevant to investors beyond that provided by aggregate net cash flows.

\section{Acknowledgement}

The authors acknowledge funding from the Ministry of Education, Science and Technological Development of the Republic of Serbia through research projects 47009, 179015, and 179001.

\section{REFERENCES}

[1] Alagathurai, A. (2013). A nexus between liquidity \& profitability: a study of trading companies in Sri Lanka. European Journal of Business and Management, 5(7), 221-237.

[2] Andjelic, S., Gajic, A., \& Ilic, Dj. (2016). Problems of Financial Management in the Public Sector. Economic Analysis, 49(3-4), 48-68.

[3] Baltagi, B.H. (2005). Econometric Analysis of Panel Data, Third edition, John Wiley \& Sons Ltd, England.

[4] Ben-Caleb, E., Olubukunola, U., \& Uwuigbe, U. (2013). Liquidity management and profitability of manufacturing companies in Nigeria. IOSR Journal of Business and Management, 9(1), 13-21.

[5] Bolek, M. \& Wili'nski, W. (2012). The influence of liquidity on profitability of polish construction sector companies. e-Finanse: Financial Internet Quarterly, 8(1), 38-52.

[6] Carslaw, C.A. \& Mills, J.R. (1991). Developing Ratios for Effective Cash Flow Statement Analysis. Journal of Accountancy, 11, 63-69. 
[7] Charitou, A., Clubb, C., \& Andreou, A. (2000). The value relevance of earnings and cash flows: empirical evidence for Japan. Journal of International Financial Management \& Accounting, 11(1), 1-22.

[8] Checkley, K. (1999). Cash is Still King: The Survival Guide to Cash Flow Management, Chicago and London: Fitzroy Dearborn Publishers.

[9] CIMA - Charted Institute of Management Accountants. (2010). Improving cash flow using credit management the outline case, 1-28, UK: Chartered Institute of Management Accountants.

[10] Clinch, G., Sidhu, B., \& Sin, S. (2002). The usefulness of direct and indirect cash flow disclosures. Review of Accounting Studies, 7(4), 383-404.

[11] Dencic-Mlihajlov, K. (2015). Profitability during the financial crisis: evidence from the regulated capital market in Serbia. South-Eastern Europe Journal of Economics, 12(1), 7-33.

[12] Duhovnik, M. (2008). Improvements of the cash-flow statement control function in financial reporting. Zbornik radova Ekonomskog fakulteta u Rijeci: casopis za ekonomsku teoriju i praksu, 26(1), 123-150.

[13] Eljelly, A.M. (2004). Liquidity-profitability tradeoff: An empirical investigation in an emerging market. International journal of commerce and management, 14(2), 48-61. DOI:10.1108/10569210480000179

[14] Figlewicz, R.E. \& Zeller, T.I. (1991). An Analysis of Performance, Liquidity, Coverage and Capital Ratios from the Statement of Cash Flow. Acron Business and Economic Review, 22(1), 64-91.

[15] Ghasemi, M. \& Ab Razak, N.H. (2016). The Impact of Liquidity on the Capital Structure: Evidence from Malaysia. International Journal of Economics and Finance, 8(10), 130-139. DOI:10.5539/ijef.v8n10p130

[16] Giacomino, D.E., Mielke, D.E. (1993). Cash Flows: Another Approach to Ratio Analysis. Journal of Accountancy, 175(3), 55-58.

[17] GRS - Government of the Republic of Serbia, Poglavlje 27: Zivotna sredina. //http://www.eu-pregovori.rs/src/pregovaracka-poglavlja/poglavlje-27-zivotna-sredina/ [retreived: 10.6.2018].

[18] Hovakimian, A., \& Hovakimian, G. (2009). Cash flow sensitivity of investment. European Financial Management, 15(1), 47-65. DOI:10.1111/j.1468-036X.2007.00420.x

[19] Huang, W., \& Mazouz, K. (2018). Excess cash, trading continuity, and liquidity risk. Journal of Corporate Finance, 48, 275-291. DOI:10.1016/j.jcorpfin.2017.11.005

[20] Hussain, N., Rigoni, U., \& Cavezzali, E. (2018). Does it pay to be really good? Looking inside the black box of the relationship between sustainability performance and financial performance. Corporate Social Responsibility and Environmental Management 25, 1198-1211. DOI:10.1002/csr.1631

[21] Isik, O. \& Tasgin, U.F. (2017). Profitability and Its Determinants in Turkish Manufacturing Industry: Evidence from a Dynamic Panel Model. International Journal of Economics and Finance, 9(8), 66-75. DOI:10.5539/ijef.v9n8p66

[22] Jovanovic, D., Todorovic, M. \& Grbic, M. (2017). Financial Indicators as Predictors of Illiquidity. Romanian Journal for Economic Forecasting, 20(1), 128-149.

[23] Khidmat, W. \& Rehman, M. (2014). Impact of liquidity and solvency on profitability chemical sector of Pakistan. Economics Management Innovation, 6(3), 34-67.

[24] Kieso, D.E., Weygandt, J.J., \& Warfield, T.D. (2010). Intermediate Accounting, IFRS edition, John Wiley \& Sons.

[25] Lukic, R. (2012). Sustainable development of retail in Serbia. Revista de Management Comparat International, 13(4), 574.

[26] Milosavljevic, M., Milanovic, N., \& Benkovic, S. (2016). Drivers of performance measurement use: Empirical evidence from Serbia. Management: Journal of Sustainable Business and Management Solutions in Emerging Economies, 21 (78), 33-43. DOI: 10.7595/management.fon.2018.0009

[27] Mulford, C. \& Comiskey, E. (2005). Creative Cash Flow Reporting: Uncovering Sustainable Financial Performance, New Jersey: John Wiley \& Sons, Inc. Hoboken.

[28] Penman, S.H. (2007). Financial Statement Analysis and Security Valuation, New York: Mc Graw Hill.

[29] Pervan, M. \& Visic, J. (2012). Influence of firm size on its business success. Croatian Operational Research Review, 3(1), 213-223. DOI: 10.17535

[30] Pervan, M., Pervan, I., \& Todoric, M. (2012). Firm ownership and performance: Evidence for Croatian listed firms. World Academy of Science, Engineering and Technology, 61, 964-970.

[31] Priya, K. \& Nimalathasan, B. (2013). Liquidity management and profitability: A case study of listed manufacturing companies in Sri Lanka. International Journal of Technological Exploration and Learning, 2(4), 161-165.

[32] Rad, H., Low, R.K.Y., \& Faff, R. (2016). The profitability of pairs trading strategies: distance, cointegration and copula methods. Quantitative Finance, 16(10), 1541-1558. DOI:10.1080/14697688.2016.1164337

[33] Rehman, M.Z., Khan, M.N., \& Khokhar, I. (2015). Investigating liquidity-profitability relationship: Evidence from companies listed in Saudi stock exchange (Tadawul). Journal of Applied Finance and Banking, 5(3), 159-173.

[34] Rujoub, M.A., Cook, D.M., \& Hay, L.E. (1995). Using Cash Flow Ratios To Predict Business Failures. Journal of Managerial Issues, 7(1), 75-90. 
[35] Safdar, M.Z., Awan, M.Z., Ahmed, Z., Qureshi, M.I., \& Hasnain, T. (2016). What Does Matter? Liquidity or Profitability: A Case of Sugar Industry in Pakistan. International Journal of Economics and Financial Issues, 6(3), 144-152.

[36] Saleem, Q. \& Rehman, R.U. (2011). Impacts of liquidity ratios on profitability. Interdisciplinary Journal of Research in Business, 1(7), 95-98.

[37] SBRA - Serbian Business Registers Agency, Registar finansijskih izvestaja pravnih lica i preduzetnika, //http://www.apr.gov.rs [retrieved: 13.12.2017].

[38] SEPA - Serbian Environmental Protection Agency, Dostavljanje podataka za Nacionalni registar izvora zagađivanja, // [retrieved: 07.07.2017].

[39] Simutin, M. (2010). Excess cash and stock returns. Financial Management, 39(3), 1197-1222. DOI:10.1111/j.1755-053X.2010.01109.x

[40] Stevanovic, S. \& Marinkovic, G. (2018). Illiquidity Risk of Polluting Enterprises in Serbia. Monography Sustainable Growth and Development in Small Open Economies: 73-87. Budapest: Institute of World Economics - Centre for Economic and Regional Studies of the Hungarian Academy of Sciences.

[41] Vastola, V., Russo, A., \& Vurro, C. (2017). Dealing with cultural differences in environmental management: Exploring the CEP-CFP relationship. Ecological Economics, 134, 267-275. DOI: 10.1016/j.ecolecon.2016.11.006

[42] Vătavu, S. (2014). The Determinants of Profitability in Companies Listed on the Bucharest Stock Exchange. Annals of the University of Petroşani Economics, 14(1), 329-338.

[43] Vieira, R. (2010). The relationship between liquidity and profitability: An exploratory study of airline companies between 2005 and 2008", Retrieved from .

[44] Wu, Q., Hao, Y., \& Lu, J. (2018). Air pollution, stock returns, and trading activities in China. Pacific-Basin Finance Journal, 51, 342-365. DOI: 10.1016/j.pacfin.2018.08.018

[45] Zainudin, N. (2006). Liquidity-profitability trade-off: is it evident among Malaysian SMEs?. International Journal of Management Studies (IJMS), 13(2), 107-118.

[46] Zenzerovic, R. (2009). Business' Financial Problems Prediction-Croatian Experience. Economic research-Ekonomska istrazivanja, 22(4), 1-15. DOI: 10.1080/1331677X.2009.11517387

[47] Zygmunt, J. (2013). Does liquidity impact on profitability. In Proceedings of the conference of informatics and management sciences, 25-29 March, Zilina, Slovakia, pp. 38-49.

Received: 2018-10-12

Revisions requested: 2018-11-30

Revised: 2018-12-25

Accepted: 2019-01-30

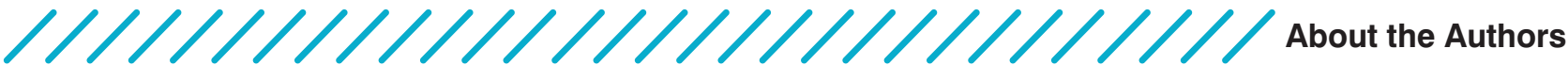

\author{
Slavica Stevanović \\ Institute of Economic Sciences, Belgrade, Serbia \\ e-mail: slavica.stevanovic@ien.bg.ac.rs
}

Slavica Stevanović, PhD is employed as a Research Associate at the Institute of Economic Sciences in Belgrade. She graduated and she got her magister degree at the Faculty of Economics, University of Belgrade. She acquired her PhD degree at the Belgrade Banking Academy - Faculty for Banking, Insurance, and Financing, University

Union in Belgrade. Slavica participated in international and national scientific conferences and was an author and co-author of numerous scientific papers. Her research interests are financial reporting and analyses, cash flow analyses, accounting, and environmental reporting and accounting. She is engaged in several domestic and international projects, and she is an editor of the annual publication named: National Network for Medium Enterprises in the Republic of Serbia,

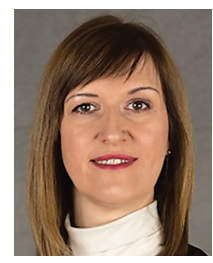
published by the Institute of Economic Sciences. 


\section{Jelena Minović \\ Institute of Economic Sciences, Belgrade, Serbia \\ e-mail: jelena.minovic@ien.bg.ac.rs}

Jelena Minović, PhD is Senior Research Associate at the Institute of Economic Sciences in Belgrade. She acquired her PhD degree (2012) at the Faculty of Economics, University of Belgrade. Jelena completed her studies at the European Business School (EBS University) in Wiesbaden, Germany for post-doc research stay from May 2013 to

August 2013. Jelena participated in many international and national conferences. She was an author and co-author of a significant number of papers (about 70). Her research interests are: Quantitative Methods and Models in Finance and Economics,

Econometrics, Time Series Analysis, Financial Economics and Financial Markets. Her articles have been published in various international journals, such as Applied Economics, Economic Research, Panoeconomicus, Engineering Economics, International Journal of Engineering Education, Economic Annals, Theoretical and Applied Economics, and others.

Isidora Ljumović Institute of Economic Sciences, Belgrade, Serbia e-mail: isidora.ljumovic@ien.bg.ac.rs

Isidora Ljumović, PhD is employed as a Senior Research Associate at the Institute of Economic Sciences in Belgrade. She graduated in the field of organizational sciences, and she got her master and PhD degrees in the field of

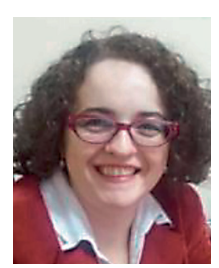
g. She is engaged in several domestic and international projects, among which are projects financed by the MESTD RoS, the World Bank, the European Union and other international donors. She has published two monographs, numerous scientific papers in domestic and international scientific journals and has participated in scientific conferences in Serbia and abroad. 